\title{
Narratives of violence: the white imagiNation and the making of black masculinity in City of God
}

\author{
Jaime do Amparo-Alves \\ Doutorando em Antropologia Social (University of Texas, Austin) \\ Assessor de políticas públicas da Educafro (Educação e Cidadania de Afrodescendentes e \\ Carentes) \\ Salvador, Brasil \\ amparoalves@gmail.com
}

\begin{abstract}
The article explores the regimes of representation of young Black men in the film $C$ ity of $\mathrm{G}$ od. The main argument is that the movie deploys pathological scripts of Black men as criminal and deviant to disseminate meanings over black masculinity in Brazil. T he author suggests that the controlling image of Black men bodies as a source of danger and impurity sustains Brazilian racial hegemony; ultimately, the narratives of violence makes explicit the ways the Brazilian nation is imagined through racial underpinning. The dual bind through which the nation is ambiguously imagined is made explicit also in the consumption of Blackness as exotic at the same time that it represents a threat to the national harmony. The nation is then written and re-imagined as a racial paradise even/and mostly by inscribing death to the black body.
\end{abstract}

Key-words: black masculinity; race; sexuality; nation; urban violence.

$\mathrm{C}$ ITY OF G OD'S controlling images of Black men need to be contextualized within the system of beliefs and practices in which Black manhood is constructed as synonymous of violence, virility, and savagery. In other words, the social construction of Black men as such informs and is informed by a racial imaginary that treats them as natural criminals. In this stigmatizing regime of representation, I suggest, mass media's discursive dehumanization of Black males should be read as symbolic violence that legitimates and informs practices of physical domination.

Also, as I shall elaborate bellow, in the process of controlling image of predominantly Black urban areas, mass media also create pathologized social geographies in which the "favelas" (the Brazilian shanty towns) are constructed as the place per excellence to which state's technologies of contention (I should say terror) are deployed to contain the Black body in zones of exclusion. H elicopters, sophisticated weapons, outlaw police officers, cameras, reporters and a series of paraphernalia transform the favela into a true hell. It is in the context of the militarization of public security and the culture of fear manufactured by the press that the favela is reinforced in the white imagination as a place of disorder and its inhabitants as potential criminals. The presence of state-terror in the favela is rationalized as domination necessary to guarantee harmony and minimize conflicts.

That the urban geography of B razilian metropolitan citiesis forged in such racialized narratives of violence is evidenced in the statistics of deadly violence. According to official data from DATASU S/ B razilian Bureau C ensus, from 1996 to 2006 homicide among youth aged 15-24 
years old have increased $31.3 \%$ in Brazil. The homicide rate among youth is 170\% higher than among the overall population. Even worse, $92.1 \%$ of the victims are young males. Indeed, the homicide rate among the black population is $73.1 \%$ higher than among whites. In states like Paraiba and A lagoas, the victimization rate of blacks accounts for as much as $700 \%$ (W aiselfisz, 2006, p. 24). D rug trafficking, organized crime, and street gangs are some of the factors in the victimization of Black youth, but they are far from being the only ones.

A point in case isthe fact that still nowadays, police reports have the telling description 'the suspect element is of standard color' to refer to Black individuals. R esearchers such as I gnacio C ano (1997), Jorge Silva (2002) and Vilma R eis (2005) have shown that Black males are the main victims not only of criminals but also of the police. W hile police lethal ity data on race is vague in Brazil, official data show that between 1995 and June of 2006, the military police in SP killed 5.473. Just in one year (2008), 2189 people were killed by the military and the civil police in Bahia. And in the state of $\mathrm{R}$ io de Janeiro the police killing is rampant. Between 2003 and 2007 the M ilitary Police killed 5616 people in R io (see Silva and C arneiro 2009).

Yet, in this paper state violence is meant by not only the lethal police force against young black men, but also state complicity with neoliberal policies that sustain the reproduction of poverty, unemployment, and social marginalization. A s $\mathrm{C}$ arole $\mathrm{N}$ agengast contends, "insofar as it is tolerated or encouraged by states in order to create, justify, excuse, explain, or enforce hierarchies of difference and relations of inequality, are acts of state violence, even though states themselves may not appear on the surface to be primary agents" (N agengast, 1994, p. 114).

As I shall consider later, instead of discussing the structural causes of deadly violence in urban Brazil, $C$ ity of $\mathrm{G}$ od explains violence as a problem of dysfunctional families and deficient Black culture. Thus, the massacre of young black men becomes normal in everyday discourse and is justified as a collateral effect of a legitimate war against criminals. H ere, the language of racial democracy miraculously erases the color of dead bodies and the structural causes of violence.

By putting Black male at the center of this analysis, this paper should not be read as claiming black men's experience as paradigmatic of Black condition. Devon $C$ arbado has called such male- centric definition of racial oppression by 'gendered construction of black racial victimhood' (C arbado, 1999, p. 4). According to him, by taking a heterosexual black man as the main victim of racism, scholars have "left unarticulated the complex ways in which race, sexual orientation, and gender function as compounding categories of subordination" (p. 9). W hile D evon's critique must be taken very seriously, by putting black men at the center of my analysis I intend not to claim them as the paradigmatic victims of racial oppression in Brazil. M y goal is to present a critique of racialized system representations of Black masculinity that disempowers the black community, as well as how the black man body came to be a field of state intervention.

In an attempt to develop such ideas, my provisional conclusions are that i) $C$ ity of $G$ od exemplifies common-sense understanding on the public image of Black men as criminals; ii) the pathologization of communities of color (the favelas) as place of criminality, danger, and fear are discursive ideological apparatus by which racial domination effectively takes place in urban Brazil.

\section{City of God: cruelty and evilness in the making of black masculinity}

C ity of $G$ od is based on an ethnographic work done by Paulo Lins. The movie, directed by Fernando M eirelles and K atia Lund in 2002, is a story telling of the favela Cidade de Deus, [in English 'C ity of $\mathrm{God}$ '], in the western zone of R io de Janeiro. The story is told from the viewpoint of a young Black teenager called R ocket (Luis 0 tavio), who is portrayed as an honest, innocent, sweet boy that dreams of being a famous photographer. The flashback narrative invites the viewer to as far back as the $60 \mathrm{~s}$, when the favela was occupied by poor inhabitants of the city. The main agent of violence in $C$ ity of $G$ od is Dadinho (D ouglas Firmino), who becomes Little Zé (Leandro Firmino) as a gang name, the most feared drug dealer in the favela and one of the most wanted criminal by R io de Janeiro's police. Little Zé and $R$ ocket's childhood is situated in a hyper violent, dirty, ugly favela where everybody is potentially criminals. The first scene on the screen is a metaphor for this, in which a group of men pursue a chicken. The scene prepares the viewer for what is coming next: the violent performance of young black males who terrorize the favela.

Both R ocket and Little Zé are the two symbolic figures through which racist stereotypes of the favela and its residents are organized. $R$ ocket is the one who becomes a good person, a docile, domesticated boy in spite of his 'natural' tendency to criminality; it is $\mathrm{R}$ ocket who tells the story of violence and desperation in the endless dispute among the gangs in the area. Little Zé, the feared head of the gang, is depicted as a hyper-violent drug dealer. R ocket and Little Zé's lives intersect in their childhood, but contrary to the former, Zé "chooses" the wrong way. In the movie, social suffering, criminality and access of citizenship are a matter of individual choice. 
In fact, Zé is a beyond-repair natural-borncriminal. The filmmakers make no concession about his life. Little Zé's pathological behavior is the center piece through which the movie narrative is organized. In a remarkable scene, the viewer is invited to engage in Little Zé's life story: he is a 12-year-old Black boy who develops a striving plan of robbery in a motel in R io's dow ntown. Leading a group of B lack youth, Little Zé shows all his criminal instincts in the bloodshed in R io's rich/white area. The disturbing scene shows white clients being killed by the Black child. D esperation and horror are contrasted with the pleasure and insatiable will to kill. The scene is closed with the narrator's voice: "on that night, Little Zé satisfied his thirst to kill." And to reinforce his criminal instinct, the narrator informs that "at eighteen, Little Zé was the most feared and most respected hood in C ity of $\mathrm{G}$ od".

The scene of the massacre depicts a perverse child that embodies evil; he kills his victims while laughing and playing with his gun. M ore than that, disturbing is the savagery of the child and the impotence of his victims. The catharsis created in this scene is the sympathetic relation of the viewer with the victims and the predicable disapproval of Zé's evilness.

$R$ apes, crimes, and drug are the elements around which the narrative of masculinity is structured in the movie. Contrary to Benny, (the coolest gangster in $($ ity of $\mathrm{G}$ od) a light skin partner in the drug business, Little Zé is portrayed as the dangerous and ugly man in the favela. Zé's hyper-sexuality is explored in his possessiveness of women in the hood. Little Zé has to pay for having sex or rape women. It is in a rape scene that his sexuality is most explored in the movie. Zé and his gang invade the house of $M$ ané Galinha, a cool hardworking guy that refused to be part in the drug-business in the favela. $M$ ané $G$ alinha's fiancé (Sabrina R osa) - that the character has no name in the movie is telling on the place reserved to Black women in the work -, is raped and members of his family are killed. Left alive, Galinha joins the rival gang lead by Sandro C enoura ( $M$ atheus $N$ achtergaele), a white easy-going dealer who refuses to 'employ' him for his decency and honesty. Galinha ends up being an important soldier in the endless war against Little Zé and his gang.

The depiction of the male figures in C ity of $G$ od suggests some hegemonic understanding regarding Black masculinity in urban B razil. The subaltern masculinity of Black men becomes hegemonic in the representations of violence the movie is invested in portray. In the same vein, the hegemonic masculinity of white manhood is made peripheral: the role played by the white consumer of drug T hiago (D aniel Z ettel) or by the white drug dealer Sandro C enoura is defined in opposition to the aggressive masculinity of black men in the movie.
In the same vein, Black masculinity is defined not only in aggressiveness and madness of Little Zé and his gang, but also in the docility and passivity of $\mathrm{R}$ ocket. This narrator-personage is able to transit between the two physical and symbolic worlds - the crudity of the favela and the harmonious areas of downtown $\mathrm{R}$ io - transforming himself in the process. $\mathrm{H}$ is docility is the green card to the world of civility and order suggested by his acceptance in the new sroom of a mainstream new spaper. A lthough he 'becomes' a man having sex with the white journalist and by joining the white male colleagues in the new sroom, approval of his masculinity is given conditionally. Little Zé and R ocket are not too far from each other, as the movie seems to suggest. They are the two sides of the same coin: a pathologiz ed script of black masculinity.

The literature on masculinities has stressed the existence of different access to the privileges of masculinity. M ost importantly, scholars have criticized the paradigm of masculinity studies for not interrogating power maintained by hegemonic masculinities, that is, white heterosexual manhood (see Gardiner 2002). In an ethnographic account of funk dance nights, gangs of jiu-jitsu practioners, and charming black club frequenters in $\mathrm{R}$ io de Janeiro, C ecchetto (2004) discusses the different stiles of masculinity developed by young men in the context of violence in the city. She found an honor code to live masculinity through virility, consumption of drug and explicit violence among young black men residing in the favela, and the jiu-jitsu gangs, while among black frequenters of class clubs she noticed an investment in a style of masculinity that emphasizes the conquest of women - the hunter men. The author suggests that there is no correlation between masculinity, violence, and poverty.

It is this correlation that the film intends to prove: violence is a masculinized characteristic that informs black manhood; manhood, on its turn, is informed by race, heterosexuality, virility, and aggressiveness. By putting guns in the hands of black children, $C$ ity of $G$ od shows the perpetuation of crime and violence through different generations in the favela. M ost importantly, the movie shows the ideal-type of manhood in the degrading environment of the favela. The 10-year-old Steak, the newest member of Zé's gang, has his baptism by shooting dead another child in the favela. It is by his performance as a "man" that he becomes recognized by the other members of the gang as one of them. Later on, when a rival gangster chastises him, he gives the following answer:

Knockout Ned - G et out of this life boy, you are just a kid.

Steak - A kid? A re you kidding? I smoke, snort, I've killed and I've robbed. I'm a man. 
The narrative of violence in $C$ ity of $G$ od is dehistoricized, depoliticized, and decontextualized. The movie invests in the rhetoric of civil war and overemphasizes the power of drug dealers to explain that $C$ idade de $D$ eus is an outlaw land. Here again, the Black male's body is the center of a spectacle of horror where death is banalized and violence becomes the only way to solve conflicts. Portrayed as cold-blooded criminals that kill anyone who cross their way, black males are no more then voracious animals. In this context, the construction of black masculinity is organized around the idea of wickedness. The aggressive performance and disposition of the bodies on the screen is strategically used through technological sophistication to harmoniously integrate the geography of the favela and the cartography of the black body. $V$ iolence is thus the key organizer of black manhood in the movie. The message stated in the images is that to be a black male is to be a source of constant danger and crime; it is to be irrational, marginal, cruel.

C ontemporary scholarship on masculinity in B razil has been mainly concentrated in the field of public health and urban sociology, stressing the relationship between manhood and violence (Batista, 2005; Lima, 2003; C ecchetto, 1997; M ontei ro, 1999). Still lacking is an integrated analysis on gender, race and violence in Brazil. The work of 0 smundo Pinho (2005) and José Jorge de C arvalho (1996) are some of the very few attempts to discuss racialized forms of masculinity in the context of violence and social exclusion.

Some of the literature on Black males has recognized Black men's complicity with patriarchy, and moved beyond universalist/ naïve critiques that do not recognize/question the politics of representation of Black masculinity (see Jackson 2006; Hooks, 1992). According to them, the ways Black men are interpolated as subaltern masculinity must be understood within the context of racial script in which the Black body is economized as the deviant 0 ther. This literature, mainly composed by black scholars, has proposed different ways Black men have lived their gender identity. As Bell Hooks points out,

[this universalist critique] does not interrogate the conventional construction of patriarchal masculinity or question the extent to which Black men have internalized this norm. It never assumes the existence of Black men whose creative agency has enabled them to subvert norms and develop ways of thinking about masculinity that challenges patriarchy (H ooks, 1992, p. 89).

In the same way, Bell Hooks (2004) has also stressed that patriarchal masculinity is pervasive. As she notes, "[t]he mainstream society has invested in pushing the notion that all that black men need to do to survive is to become better patriarchs" (H ooks, 2004, p. xiv). She argues that in order to deconstruct this culture of domination, Black males must refuse to take part in white patriarchy; "they need to know that their ambivalent position as males in a white patriarchal world will never be fulfilled" (p. 66).

Thus, in conversations regarding the social construction of black masculinity it is important to ask to which forces young Black men are responding to when they engage in supposedly deviant behaviors (see Gordon 1997). In that sense, Edmond Gordon (1997), for instance, urges us to see black men's practices as more than a social problem as traditional literature has suggested. $0 \mathrm{n}$ the contrary, " [t] he 'problem' of black males, generally couched in psychological and sociological terms (e.g., hypersexuality, deviance, immorality, delinquency, and criminality) must be thought of in political terms (see Gordon 1997, p. 47).

\section{Racialized Regime of Representation}

H ow is the narrative of violence constructed and structured in C ity of $\mathrm{G}$ od? D rawing on Bordieu's earlier formulations on symbolic violence, this paper suggests that the mass media is a privileged place where hegemonic pathologized discourse on Black masculinity is symbolically constructed.

According to Bourdieu (1995), symbolic violence is a set of beliefs and practices imposed by the dominant class to reproduce the social structure of a given society. As a coercive power, in its symbolic form, violence is a tool to social classification and dehumanization of individuals. T he institutionalized discourses about the world are, in Bourdieu's view, a dialectic process marked by both the "incorporation of structures" and by the "ritualization of practices" The author argues that the maintenance and reproduction of the symbolic order is exercised through inculcation and appropriation; it is when this system of dispositions becomes a taken-for granted, commonsense social order that this set of practices and beliefs becomes what Bordieu names as habitus, that is, it becomes internalized as subjective ritualization of the "objective social structure" (Bourdieu, 1995, p. 166).

The category 'habitus' is important here because it allows us to unveil the mechanisms by which ideology sustains relations of domination grounded on the uses and productions of myths, thoughts, perceptions, expressions, actions, language, and so on (Bourdieu, 1995, p. 85). At this point, I would suggest that as a shared habitus, the systematic dehumanization of black youth in popular culture can be understood as institutionalized modes of domination. Because this set of practices and beliefs is articulated in everyday life as naturally given, symbolic violence becomes pervasive within the whole society, and legitimates physical forms of violence against the black body. 
In Ideology and M odern C ulture, John Thompson (1995) has argued that to study ideology in the mass media is to study the ways meanings are employed to establish and sustain relations of domination. According to him, stigma is, per excellence, a symbolic construction of domination based on race, class, gender, nation, sexuality, and so on. The very categories in which stigmas and stereotypes rely on are expressions of symbolic forms of domination whereby physical violence is built on. In effect, the controlling image of the black body as a source of constant impurity, danger, and fears, has legitimized what I would call the dehumanizing process. In that sense, if the black man body is constructed as synonymous of violence, their killing is not only expected but also necessary in an environment where everybody seems to incorporate evil, as the film $C$ ity of $G$ od suggests.

The movie seems so invested in the rhetoric of war and in portraying black-on-black violence that it fails to address the role of the State in the victimization of black youth in the favela. There is no sense of community solidarity in the $\mathrm{C}$ ity of $\mathrm{G}$ od. Indeed, there is no way out of the pathological cycle of violence that organizes the social life in the favela. 0 nly through the elimination of the black body will the society be protected from the horror that the black presence inconveniently represents. Violence is, then, dehistoricized, depoliticized, and de-contextualized.

A uthors such as M aria D amasceno (2000), M ariza C orrea (1996), Patricia C ollins (2005), among others, have highlighted the role played by the popular culture industry in perpetuating stereotypes based on sexuality, gender, and race. Common to these authors is the opinion that the media's repertoire of images equals symbolic forms of domination that regulate, commodify, and de-politicize the black image. From the Brazilian invention of both the mulata and the sanguinary black criminal to the U S racist construction of the Black woman as jezebels and mammies, the black body is tied to a stigmatized regime of representation used to spread the ideology of this "new racism", as Collins calls it, that consumes images of the black body as deviant and/or exceptional.

$R$ onald Jackson (2006) has called this system of representation by 'polysemous hegemonic inscriptions of Black bodies' (Jackson, 2006, p. 123). According to him, the pathological depictions of the black men body are an inscriptive surface where polysemic texts are w ritten: black men body is racially scripted as uneducated, violent, exotic, sexual, exploitable, incapacitated (see Jackson, 2006, p. 46).

$T$ he representation of $B$ lack people has been organized under the master $X$ enslaved relation: it is in that sense that it is correct to affirm that a movie like $C$ ity of $\mathrm{G}$ od just updates the racial hierarchy inscribed in the racial structure of domination from the colonial era, that is, the mass media representations of blackness up- date the colonial order in our (post) colonial moment. In T he L ocation of C ulture, H omi Bhabha has argued that "the colonial discourse produces the colonized as a fixed reality which is at once and 'other' and yet entirely knowable and visible (Bhabha, 1990, p. 41)". It is, from this 'field of enunciation' that stereotypes are created to construct a repertoire of signifying practices in the exercise of power. A s the author points out:

The construction of the colonial subject in discourse, and the exercise of colonial power through discourse, demands an articulation of forms of difference - racial and sexual. Such an articulation becomes crucial if it is held that the body is always simultaneously inscribed in both the economy of pleasure and desire and the economy of discourse, domination, and power (Bahbha, 1990, p. 38).

In that sense, the media's totalizing narratives of violence in the urban landscape is based on a web of meanings over the Black body that marks it as the 0 ther. The culture of spectatorship over otherness in Brazilian mass media is based on a 'racialized regime of representation' ( $\mathrm{H}$ all, 1997), whereby the 0 ther is suspended in a system of signifying practices mobilized around fear and anxieties. As Stuart $\mathrm{H}$ all (1997) is able to show in another context, within such regimes of representation racialized bodies became the discursive site to perform the making of difference:

Typical of this racialized regime of representation was the practice of reducing the culture of black people to $\mathrm{N}$ ature, or naturalizing difference. The logic behind naturalization is simple. If 'differences' between blacks and whites people are cultural, then they are open to modification and change. But if they are 'natural' - as the slave-holders believed -, then they are beyond history, permanent, and fixed. ' $N$ aturalization' is therefore a representational strategy designed to fix 'difference' and thus secure it forever. It is an attempt to halt the inevitable 'slide' of meaning to secure discursive or ideological 'closure' (H all, 1997, p. 245).

Thus, race and sexuality are two important fields of intervention through which dehumanization of racial 0 thers are discursively and physically enacted in the context of everyday life. As I have explored so far, the hegemonic discourse on heterosexuality, violence, and fear to construct black male's masculinity narrative in $C$ ity of $\mathrm{G}$ od can provide us with a good example of how 'racial hegemony' (see $\mathrm{H}$ anchard, 1998) works to maintain structural domination based on sex, race, class, and gender.

W hilst I engage in the aforementioned scholarship as a way to analyze 'pathologized scripts' of the black male body (Jackson, 2006; M arriot, 2004), it is also important to situate such regime beyond the re- 
alm of representation alone. According to Sander Gilmar, white obsession with the black body reveals the dialectic of stereotypes: "W e need these stereotypes to structure the world. We need cruse representations of difference to localize our anxiety, to prove ourselves that what we fear does not lie within" (Gilmar, 1985, p. 240). In the same sense, D avid $M$ arriot reveals how a 'compulsive fascination' (M arriot, 2004, p. xiv) of whites with themselves informs their consumption of Black suffering. Although it is true that the psychological dimension of racism informs racist practices, the (symbolic) killing of the black body needs to be contextualized beyond the real $m$ of individual responses to their ow $n$ obsession and situated within a systemic anti-black social system (B onilla-Silva, 1996).

In the following section, I shall contextualize C ity of $G$ od's narratives of violence making explicit that the dehumanization of black males in the mass media is one of the set of practices of domination Black people are subjected to in the Brazilian society. Thus, I suggest, we must read the dehumanizing set of practices and discourses in the mass media as symbolic violence that enforces and makes the killing of the black body possible.

\section{Racial Imaginary in the Brazilian Nation-Building}

Traditional literature on violence in Brazil (see for instance Chauí, 2000; Da M atta, 1991; Zaluar, 1994; Kant de Lima, 1994; Cano, 1997; Caldeira, 2003, among others) has been compromised for not situating urban violence within the anti-Black character of the nation. Is it not the case that there is something inherently anti-Black in the Brazilian national imaginary that makes Black bodies out of place in our brasilidade ("Brazilianness"), at the same time that Black culture becomes a currency? The project of nation never included Blacks for such a group was an obstacle to the ideal-type of modernity and civilization celebrated by the white elites. The R epublic was thought to be built under the ideology of "whitening": as the phenotype's profile of its population turns into a closer appearance with the Europeans, Brazil would achieve the status of a civilized nation (see Skidmore, 1995; M unanga, 1999).

In T here ain't no black in the U nion Jack, Paul Gilroy (1987) demonstrates that ideas on race, class, and nation produce narratives of belonging and nationhood across the political spectrum of the British nation. Arguing against B enedict A nderson's earlier formulation that racism was not a component of nationalism and that the nation was built upon print capitalism rather than on biological bases (Anderson, 2006), Gilroy shows that national membership in the English/ Britain case is grounded in the racial discourse that con- stitutes national boundaries at the same time that it denies its very existence. The process of making Britain as a pure a homogenous national ity, he suggests, is an ambivalent process for it is also a process of making 'otherness'. Cultural and biological ties are articulated to create boundaries, which he names 'new racism'. $\mathrm{N}$ ew racism, according to him,

is primarily concerned with mechanisms of inclusion and exclusion. It specifies who may legitimately belong to the national community and simultaneously advances reasons for the segregation or banishment of those whose 'origin, sentiment or citizenship' assigns them elsewhere (Gilroy, 1987, p. 250).

R egardless of the British specificity and racial formation, Gilroy's earlier argument is useful for the understanding of the Brazilian nation-building as well. W hile the notion of citizenship and national belonging in Brazil has a deeply racialized root since not every one can have access to full citizenship in this country, Blacks appear in the popular representation of the nation as the exotic object of white consumption. C arnival, samba, football, sexual tourism, and so on are incorporated into the narratives of the nation in a culturalist perspective that does both depoliticize the meanings of race at the same time that it creates this very category. Is it not that 'racial ambivalence' (see $\mathrm{H}$ ale, 2006), however, is precisely what makes the re-production of the nation so powerful in the Brazilian case? It is within this framework that I pose the follow question: how is the historical reality of colonialism updated and re-actualized in contemporary narratives of violence? H ow is violence deployed to write and to sustain the ideal-type/ the project of the Brazilian nation? These questions are important for they invite us to think about urban violence in contemporaneous Brazil, and particularly the culture of death against Black young males, as a web of events and practices informed by constructed meanings over gender, race, class, and the nation.

Post colonial theorist Homi Bhabha (1990) has contended that the nation-building is the result of a creative work of 'cultural elaboration'. As is al ready well known, Bhabha articulated insightful reflections on the ways the colonized disturbed the hegemonic codes of the colonizer by the process of 'productive ambivalence' (Bhabha, 1990, p. 67), in which the body of the colonized was not only the object of coIonial abuse, but also a vehicle of power/ subjectivity. W hat interest us in Bhabha's reflection by now is his formulation on the 'other question', that is, how the other is constructed by a web of discourses, as well as his formulation on the way differences (sexuality, race, class, gender) fit in the narration of the nation.

Bhabha invites us to read the nation as performative work. According to him, the nation is produced 
and lived by two processes: a pedagogical and a performative one. The pedagogical process would be the one learned from what Althusser (1979) had previously called Ideological State Apparatus (ISA). The school, the church, the national media, and so on are examples of the living narratives we are 'told'. The process of performing the nation, he suggests, would be the one in the constant making/becoming. We write the nation by performing the nation. And by performing the nation we contest, negotiate, re-w rite it. In that sense, the good citizens would be the ones that perform the nation with docility. It is the pedagogical process that normalizes/ disciplines the body, producing 'good' citizens. It makes docile subjects, produced by the technologies of power, as Foucault (1979) has reminded us.

Bhabha's argument is critical for offering routes to think the ways the nation is written not only in the geographical, but also in the biological body. Yet, the questions that rise from his reading are: $W$ hat happens then to some (bodies) that are inherently unfitted in the nation? Here, I would argue, lies the Black condition within the Brazilian nation: Blacks will never fulfill the ideal citizen in the Brazilian racial imaginary for w riting the nation in Brazil have historically meant erasing the Black subject, as the literature on black genocide has reminded us (see Vargas, 2005; $\mathrm{N}$ ascimento, 1989).

Jacqui Alexander (1994) has argued elsewhere that the very process of nation-building requires the discipline and regulation of 'deviant' bodies by a technology of state control aiming to reassure the reproduction of the heterosexual family. According to her, the nation is an intertwined and historical process of masculinization and heterosexualization of the state colonized notions of citizenship. Thus,

not just (any) body can be a citizen any more, for some bodies have been marked by the state as nonproductive, in pursuit of sex only for pleasure, a sex that is non-productive of babies and of no economic gain. $\mathrm{H}$ aving refused the heterosexual imperative of citizenship, these bodies, according to the state, pose a profound threat to the very survival of the nation (A lexander, 1994, p. 6).

The black body is then the symbolic place where the nation is defined. For being the essential 'other', the black body is both the anti-national - the one that disturbs the harmony of the national project - and the folkloric symbol that makes the very idea of national harmony possible. In that sense, the apparently contradiction in this paper is not a slippage. The position that Black Brazilians occupy in this nation is ambiguously marked: at the same time that the nation consumes blackness as culture, it perpetrates systemic violence against black people.
The nation is, then, performed by the politics of terror: police violence, state neglect in public services, pathologized popular representations of black people. Put simply, my argument is that the postcolonial representation of the Black other in the popular culture updates the colonial regime of representation. N ow that race as a biological category has been put under deep scrutiny, the cultural industry needs to reshape its rhetoric with a more aggressive and less explicit control over the image of racial "others." Thus, our very present now is marked by racial hegemony which, at the same time it denies the existence of race, it also organizes social life through what Brazilian scholar Lélia Gonzalez (1983) has appropriately called 'Brazilian cultural neurosis' and Judith Butler has called "white paranoia" (Butler, 1993).

The movie $C$ ity of $G$ od, I propose, needs to be understood within such larger context I have tried to outline so far. The racist imagination of its filmmakers - depicting young black men as natural-born criminals and the favela as the privileged place of evilness and moral degradation - needs to be read as part of the net of racial dominance that subjugates and kills blacks in the Brazilian urban setting.

\section{Conclusion}

By looking into the politics of representation of Black men in the popular culture, I suggested that the controlling image of Black male as criminal, ugly, polluted, and evil is one of the strategies by which racial meanings are produced paving the way to the killing of young black men in Brazilian favelas. Black men experience is not, by any means, the quintessential kind of oppression Black people have been submitted throughout the African D iaspora. In this paper I privileged Black men encounters with a specific kind of violence (homicidal violence) and its representation in popular culture.

In that context, I suggested, the narrative of black masculinity in $C$ ity of $\mathrm{G}$ od is organized around three foundations: violence, sexuality, and race. R ocket [Buscapé] is the exception among the black youth that fail in disgrace in the favela. 0 nly by becoming a hard-worker was he able to resist the pathological fatality of living in the favela. Little Zé, on the other hand, is the one who embodies the violence in its most cruel form. In the white racist mind of $C$ ity of $\mathrm{G}$ od's filmmakers, Zé represents the natural born, out- of-control criminal. Since he does not fulfill the requirements to fully participate in the white world, to be recognized as male he must be feared, must have outstanding sexual performance, and must prove his manhood at any cost. 


\section{References}

ALEX AN DER, Jacqui. N ot just (any) body can be a citizen: the politics of law, sexuality and postcoloniality in Trinidad and Tobago and the Bahamas. Feminist R eview, $n$. 48, p. 5-23, 1994.

ALTH U SSER, Louis. Ideology and ideological state apparatuses. In: . L enin and philosophy and other essays. London: N ew Left Books, 1979.

AN DER SO N, Bendedict. Imagined communities. London, N ew York: Verso, 2006.

BATIST A, LuísE duardo. M asculinidade, raça/ cor e saúde. C iência \& Saúde C oletiva, v.10, n.1, p.71-80, 2005.

BHABHA, Homi. Nation and narration. London: Routledge, 1990.

- The other question. In: MONGIA, Padmini (Ed.). C ontemporary postcolonial theory: a reader. $\mathrm{N}$ ew York: O xford U niversity Press, 1996.

BOUR DIEU, Pierre. 0 utline of a theory of practice. Cambridge: C ambridge U niversity Press, 1977.

BU TLER, Judith. Endangered/endangering: schematic racism and white paranoia. In: GOO DIN G-W I LLIAM S, R obert ( $E d$.). R eading R odney $K$ ing/ R eading urban uprising. London: R outledge, 1993.

CALDEIR A, Teresa. C ity of walls: crime, segregation, and citizenship in São Paulo. Berkeley: U niversity of California Press, 2003.

CAN O, I gnacio. L etalidade da ação policial. $R$ io de Janeiro: ISER , 1997.

CAR BADO, Devon W. (Ed.). B lack men on race, gender, and sexuality: a critical reader. $\mathrm{N}$ ew York: $\mathrm{N}$ ew York U niversity Press, 1999.

CAR VALHO, José Jorge. I mage of the black man in Brazilian popular culture. Série A ntropologia, n. 201. Braślia: D epartamento de A ntropologia, U niversidade de Brasília, 1996.

CECCHETTO, Fatima. V iolência e estilos de masculinidades. R io de Janeiro: Ed. FGV, 2004.

CH AU Í, M arilena. B rasil, mito fundador e sociedade autoritária. São Paulo: Ed. Fundação Perseu Abramo, 2000.

COLLIN S, Patricia H ill. Black sexual politics. New York: R outledge, 2005.

COR R EA, M ariza. Sobre a invenção da mulata. C adernos Pagu, n. 6/7, p. 35-50, 1996.

DA M ATTA, R oberto. C arnavais, malandros e heróis. $R$ io de Janeiro: Z ahar, 1981.

DAM ASCEN O, Caetana M aria. 'Em casa de enforcado não se fala em corda': notas sobre a construção da boa aparência no Brasil. In: GU IM AR ÃES, Antônio Sérgio A.; H U N T LEY, Lynn (O rgs). T irando a máscara: ensaios sobre o racismo no Brasil. R io de Janeiro: Paz e Terra, 2003.

FOU CAU LT, M ichel. D iscipline and punish: the birth of the prison. N ew York: R andom H ouse, 1979.

GAR DINER, Judith. Introduction. In:

(Ed.).

$M$ asculinity studies and feminist theory: new directions. N ew York: C olumbia U niversity Press, 2002.
GILM AR, Sander. D ifference and pathology: stereotypes of race, sexuality, and madness. O xford: O xford U niversity Press, 1985.

GILROY, Paul. 'T here ain't no black in the U nion Jack': the cultural politics of race and nation. C hicago: U niversity of Chicago Press, 1987.

GO N ZA LEZ, Lélia. R acismo e sexismo na cultura brasileira. In: SILVA, Luiz A ntonio (O rg.). M ovimentos sociais, urbanos, memórias étnicas e outros estudos. Brasília, A N PO C S, 1983.

GORDON, Edmund T. Cultural politics of black masculinity. Transforming A nthropology, v 6, n. 1/2, p. 36-53, 1997.

HALE, Charles. Más que un indio ( $M$ ore than an Indian): racial ambivalence and neoliberal multiculturalism in Guatemala. Santa Fe, N M : SA R Press, 2006.

H A LL, Stuart. 0 n representations. 0 xford: 0 xford U niversity Press, 2005.

Culture, the media, and the 'ideological effect'.

In: CU R R A N , James et al. (Eds.). M ass communication and society. London: Edward A rnold, 1979.

HAN CHAR D, M ichael George. 0 rpheus and power: the 'M ovimento Negro' of R io de Janeiro and São Paulo, Brasil, 1945-1988. Princeton: Princeton University Press, 1994.

HOOKS, Bell. We real cool: black male and masculinity. N ew York: R outledge, 2004.

. R ace and representations. Boston: South Press, 1992.

. B lack looks: race and representation. Toronto: B etween Lines, 1992.

JACKSON, R onald L. Scripting the black masculine body: identity, discourse, and racial politics in popular media. A lbany, N Y: State U niversity of N ew York Press, 2006.

KANT DE LIMA, Roberto. A polícia da cidade do $R$ io de Janeiro: seus dilemas e paradoxos. $R$ io de Janeiro: Policia M ilitar do R io de Janeiro, 1987.

KELLEY, R obin D. G. Yo' mama's disfunktional! Fighting the culture wars in urban A merica. Boston: Beacon Press, 1997.

LIM A, M aria Luíza C arval ho de. A trajetória dos homiádios no estado de Pernambuco: uma abordagem epidemiológica nas duas últimas décadas do século $X X$. $R$ io de Janeiro, 2003. Tese (Doutorado em Saúde Pública) - Fundação 0 swaldo C ruz.

M A R R IOT T, David. O n black men. N ew York: Columbia U niversity Press, 2004.

M O N T EIR O, R odrigo de A raújo. Torcer, lutar, ao inimigo massacrar: R aça R ubro-N egra! U ma etnografia sobre futebol, masculinidade e violência. $R$ io de Janeiro: $E d$. FGV, 2003.

M U N A N GA, K abengele. R ediscutindo a mestiçagem no B rasil. Belo Horizonte: Autêntica, 2004.

N AGEN GAST, C arole. Violence, terror, and the crisis of 
the state. A nnual R eview of A nthropology, v. 23, p. 109-126, 1994.

N A SCIM EN TO, A bdias. B razil, misture or massacre? Essay in the genocide of a black people. Dover, M A: M ajority Press, 1989.

PAGE, Enoch H .; R ICHAR DSO N, M att U. O n the fear of small numbers: a twenty-first $C$ entury prolegomenon of the U.S. black transgender experience. In: BATTLE, Juan; BA R N ES, Sandra L. (Eds.). B lack sexualities: probing powers, passions, practices, and policies. Piscataway, $\mathrm{N} \mathrm{J}$ : R utgers U niversity Press, forthcoming.

PIN HO , O smundo de A raújo. Etnografias do brau: corpo, masculinidade e raça na reafricanização em Salvador. R e vista E studos F eministas, v.13, n.1, p. 127-145, 2005.

R EIS, Vilma. A tucaiados pelo E stado. As políticas de segurança pública implementadas nos bairros populares de Salvador e suas representações, 1991-2001. Salvador, 2005. Dissertação (M estrado em C iências Sociais) - U niversida- de Federal da Bahia.

SILVA, Jorge da. V iolência e racismo no $R$ io de Janeiro. $N$ iterói: EDU FF, 1998.

SILVA, R odnei; CAR N EIR O, Suelaine. V iolência R acial: uma leitura sobre os dados de homicídios no Brasil. São Paulo: Geledés Instituto da M ulher N egra, 2009.

THO M PSO N , John. I deology and modern culture: critical social theory in the era of mass communication. Palo A Ito: Stanford U niversity Press, 1995.

VAR GAS, João. G enocide in the A frican diaspora: U nited States, Brazil, and the need for a holistic research and political method. C ultural D ynamics, v. 17, n. 3, p. 267-290, 2005.

WA ISELFISZ, Julio Jacobo. M apa da violência IV : osjovens do Brasil. Brasília: U N ESC O/Instituto Ayrton Senna/ Secretaria Especial dos D ireitos H umanos, 2006.

ZALUAR, Alba. Condomínio do diabo. R io de Janeiro: R evan/Ed.U FR J, 1994.

\title{
Narrativas da violência: a imaginação branca e a construção da masculinidade negra em Cidade de Deus
}

\section{Resumo} \\ 0 artigo explora os regimes de representação de jovens negros no filme $C$ idade de D eus. 0 principal argumento é que o filme adota \\ papeis patológicos para os homens negros como criminosos e desviantes para disseminar significados sobre a masculinidade negra no \\ Brasil. 0 autor sugere que a imagem dominante dos corpos de homens negros como uma fonte de perigo e impureza sustenta a he- \\ gemonia racial brasileira; enfim, as narrativas de violência tornam explícitos os modos como a nação brasileira é imaginada pelo viés \\ racial. 0 duplo vínculo, pelo qual a nação é ambiguamente imaginada também se torna explícito no consumo da negritude como exó- \\ tica, ao mesmo tempo em que representa uma ameaça à harmonia nacional. A nação é então escrita e re-imaginada como um paraíso \\ racial mesmo/e principalmente inscrevendo-se a morte no corpo negro.
}

Palavras-chave: masculinidade negra; raça; sexualidade; nação; violência urbana.

\section{Narrativas de la violencia: la imaginación blanca y la construcción de la masculinidad negra em Ciudad de Dios}

\begin{abstract}
Resumen
El artículo explora los regímenes de representación de jóvenes negros en la película C iudad de D ios. El principal argumento es el de que la película adopta papeles patológicos para los hombres negros como criminosos y desviantes para divulgar significados sobre la masculinidad negra en B rasil. El autor sugiere que la imagen dominante de los cuerpos de hombres negros como una fuente de peligro e impurezas sostiene la hegemonía racial brasileña. A sí, las narrativas de violencia tornan explícitos los modos como la nación brasi leña es imaginada por la característica racial. El doble vínculo, por el cual la nación es ambiguamente imaginada, también se torna explícito en el consumo de la negritud como exótica, al mismo tiempo en que representa una amenaza a la harmonía nacional. La nación es, entonces, escrita e imaginada de nuevo como un paraíso racial mismo/y principalmente inscribiéndose la muerte en el cuerpo negro.
\end{abstract}

Palabras clave: masculinidad negra; raza; sexualidad; nación; violencia urbana. 
